\title{
Clinical features related to xeroderma pigmentosum in a Brazilian patient diagnosed at advanced age
}

This article was published in the following Dove Press journal: The Application of Clinical Genetics

\author{
Marina Guinda Ribeiro' \\ Gabriella Lucato Zunta' \\ Jéssica Silva Santos' \\ Aparecida Machado \\ Moraes $^{2}$ \\ Carmen Silvia Passos Lima \\ Manoela Marques Ortega' \\ 'Department of Post Graduate \\ Program in Health Science, São \\ Francisco University, Bragança \\ Paulista, São Paulo, Brazil; \\ ${ }^{2}$ Department of Internal Medicine, \\ Faculty of Medical Sciences, University \\ of Campinas, Campinas, São Paulo, \\ Brazil
}

\begin{abstract}
Xeroderma pigmentosum is a rare autosomal recessive genetic disease characterized by extreme sensitivity due to solar radiation and deficiency in excision repair DNA. Those factors promote a set of skin abnormalities such as keratosis, hyperpigmentation, tumors in areas exposed to sunlight, and ocular and, eventually, neurological disorders. In the present review, we summarize the main clinical features related to a case of xeroderma pigmentosum in a man who was not diagnosed until he was 45 years old.
\end{abstract}

Keywords: xeroderma pigmentosum, DNA repair-deficiency disorders, ultraviolet rays

\section{Introduction}

Xeroderma pigmentosum (XP) is a rare autosomal recessive genetic disease, characterized by deficiency in DNA repair mechanism through the nucleotide excision repair (NER) pathway, which leads to sensitivity to ultraviolet (UV) radiation, thereby promoting the appearance of cutaneous tumors, such as squamous cell carcinoma (SCC), basal cell carcinoma (BCC), and cutaneous melanoma (CM) ${ }^{1-3}$ Approximately $25 \%$ of affected individuals have neurologic manifestations like microcephaly, diminished or absent deep tendon stretch reflexes, progressive sensorineural hearing loss, and progressive cognitive impairment. ${ }^{4}$ The most common cause of death in XP patients is skin cancer, most frequently due to metastatic melanoma or invasive SCC. ${ }^{5} \mathrm{XP}$ patients who smoke have an increased risk of lung cancer compared to the general population, among other cancers, as cigarette smoke components have mutagenic effects similar to UV radiation. ${ }^{5}$ Skin cancers can also occur in unusual sites that get less UV radiation exposure, including the tongue. ${ }^{6}$ Studies also suggest that XP patients under age 20 years have increased risk for cancers of the brain and those at other central nervous system locations. ${ }^{7-9}$

NER is a very important DNA repair pathway as it deals with a wide range of structurally unrelated DNA lesions and adducts. The XP genes (XPA,ERCC3 [XPB], $X P C, E R C C 2[X P D], D D B 2[X P E], E R C C 4[X P F]$, and ERCC5 [XPG]) encode proteins that operate in NER pathway and participate in recognition, demarcation, and removal of DNA damage. ${ }^{10}$ In addition, $\mathrm{XP}$ is associated with pathogenic variants in the DNA bypass polymerase $\mathrm{POLH}(\mathrm{XPV}) .{ }^{10} \mathrm{XP}$ patients harbor mutations in at least 1 of the above genes. ${ }^{11}$

The incidence of skin cancer is 1,000 times higher in XP patients, and life expectancy is about 30 years. Actually, the median age at death in persons with XP with neurodegeneration (29 years) was found to be lower than that in XP patients without
Correspondence: Manoela Marques Ortega

São Francisco University, Av São Francisco de Assis, 218, Jardim São José, Bragança Paulista, São Paulo,

Cep 12916-900, Brazil

Tel +55 I | 2454874 |

Email manoela.ortega@usf.edu.br
The Application of Clinical Genetics 2018: I I 89-92 
neurodegeneration (37 years). ${ }^{12}$ Symptoms may begin at 8 years of age when the first lesion may appear. ${ }^{5}$

This case report comprises an XP patient seen at the Clinical Oncology Service of General Hospital of University of Campinas between 1993 and 2010.

\section{Case report}

The study was conducted for educational purposes and according to the Declaration of Helsinki, and it was approved by the Human Ethics Committee of the São Francisco University, Bragança Paulista, SP, Brazil, under protocol no. 49150215.8.0000.5514.

SLJF, a 45 year old, male, Caucasoid, farmer, smoker for 20 years/1 pack a day, sought the oncology department due to an injury in the lower left eyelid accompanied by local pain. During his familial history investigation, the patient reported a sister, 2 brothers, and a cousin with skin cancer (Figure 1); however, no details were observed in his records. He also mentioned having several tumors in his face since 13 years old, which were surgically removed, irregular use of sunscreen, and daily long period sun exposure. During clinical investigation, hyperchromic and hypochromic spots and many hyperkeratotic papules in sun exposed areas (arms and face) were observed. Therefore, no genetic and histological analysis was performed. We show here, for educational purposes, the SCC and BCC (Figure 2) tumors that were found in the face and wrist of a comparable XP patient. Etretinateretinoid chemopreventive (Tigason $®$; HoffmannLa Roche, Basel, Switzerland) was prescribed, which was further replaced by acitretin (Neotigason $®$; Hoffmann-La Roche), and the mandatory use of sunscreen. The patient was monitored monthly, and at 49 years developed CM in the face. At 50 years, he developed periorbital SCC with the left orbital wall invasion, leading to eye desiccation. At 53 years, new BCC and SCC located in same areas that were previously affected were observed. At 62 years, an inoperable recurrence of CM (Figure 3) was observed. The patient had received Taxol as chemotherapy treatment, but he died after 7 cycles.

\section{Discussion}

The peculiarity of XP is the early onset and is related to severity of lesions, which begin around the age of 2-8 years. ${ }^{5,13}$ This is justified by alteration in DNA repair capacity after sun exposure, which depending on XP type is reduced to $7.5 \%$ or less, compared to $100 \%$ in the control group. ${ }^{13}$ Although
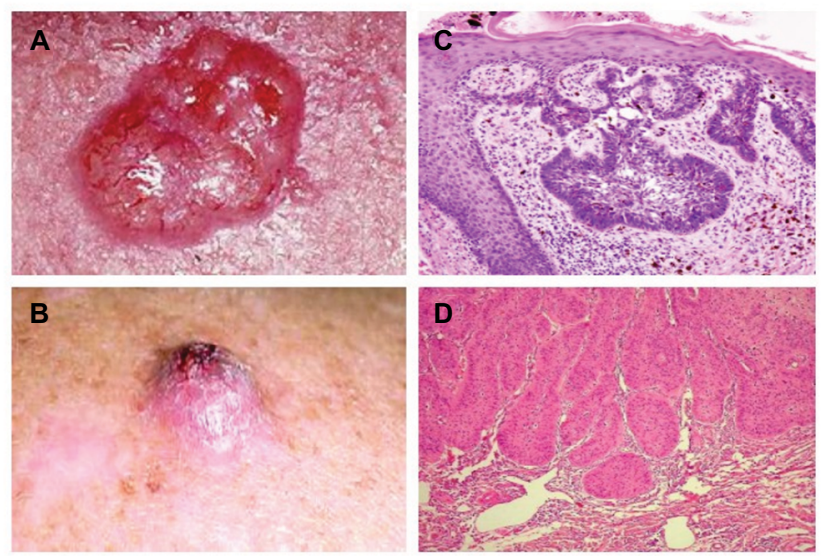

Figure 2 Illustrative pictures from a typical ulcerative of BCC and SCC from the face of an XP patient.

Notes: Illustrative pictures from a typical ulceration of BCC (reproduced from Wikimedia commons. [webpage on the Internet]. Basal Cell Carcinoma. Available from https://commons.wikimedia.org/wiki/File:Basal_cell_carcinoma.jpg. ${ }^{18}$ ) (A) and SCC (B) from the face of an XP patient. H\&E staining under $400 \times$ magnification of the BCC stained with H\&E (400×) Reproduced from Alergodermatoligia. [blog on the Internet]. Available from http://alergodermatologia.blogspot.com.br/2008/06/ cncer-da-pele.html. ${ }^{19}$ Carcinoma cells arise in the basal cells and at deepest layer of the epidermis. (C). The lesion shows neoplastic cells among the connective tissue. H\&E staining under $400 \times$ magnification of the SCC. Neoplastic epithelial cells constitute cell groups that accumulate within the connective tissue of the dermis. Available from https://commons.wikimedia.org/wiki/File:Basal_cell_carcinoma histopathology \%283\%29.jpg. ${ }^{20}$ (D) Adapted with permission from Faculty of Medical Sciences of the State University of Campinas (UNICAMP). Pathological Anatomy, Neuropathology and Neuroimaging. [webpage on the Internet]. Available from http://anatpat.unicamp.br/lamneol I.html. ${ }^{21}$ )

Abbreviations: BCC, basal cell carcinoma; H\&E, hematoxylin and eosin; SCC, squamous cell carcinoma; $\mathrm{XP}$, xeroderma pigmentosum.

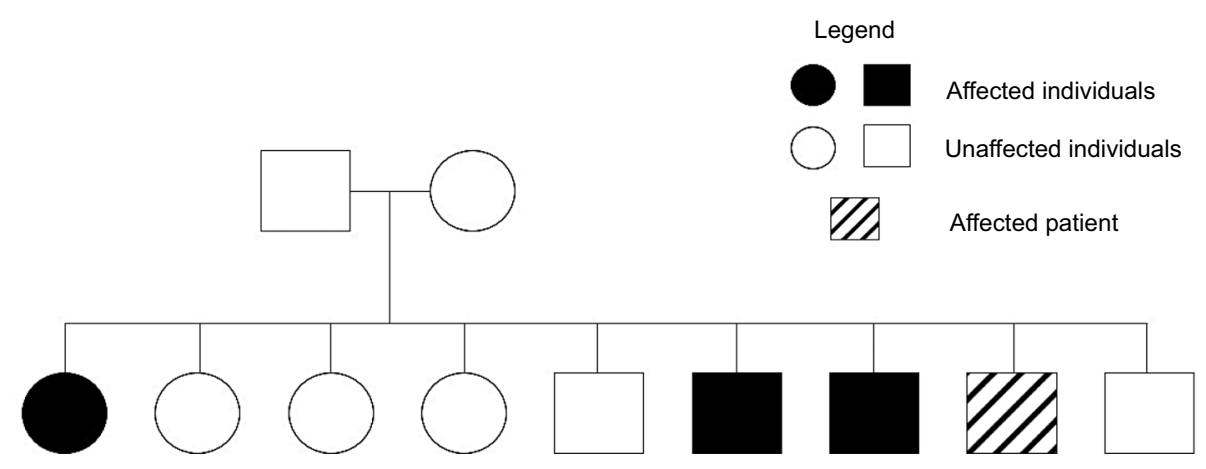

Figure I Family heredogram showing the patient's affected family members.

Notes: The patient with XP is represented by the striped square. The XP patient reported a sister (full circle), 2 brothers (solid squares), and a cousin (not shown) with skin cancer.

Abbreviation: $\mathrm{XP}$, xeroderma pigmentosum. 


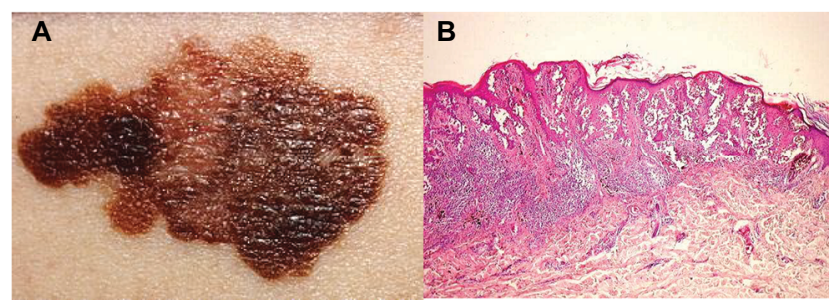

Figure 3 Illustrative pictures from a typical ulceration of CM form the face of an XP patient.

Notes: Photograph of atypical ulceration of $\mathrm{CM}$ from the face of an XP patient (A). H\&E staining under $400 \times$ magnification (reproduced from Wikipedia. [website on the Internet]. Available from https://pt.wikipedia.org/wiki/Melanoma\#/media/ File:Melanoma.jpg. ${ }^{22}$ ). CM originates from melanocytes in the basal layer of the epidermis and infiltrates the dermis (B). (Adapted with permission from Faculty of Medical Sciences of the State University of Campinas (UNICAMP). Pathologica Anatomy, Neuropathology and Neuroimaging. [webpage on the Internet]. Available from http://anatpat.unicamp.br/lamdegn $17 . \mathrm{html} .{ }^{21}$ )

Abbreviations: CM, cutaneous melanoma; H\&E, hematoxylin and eosin; XP, xeroderma pigmentosum.

our patient had delayed diagnosis of XP, he had an above average survival, probably due to follow-up after diagnosis.

Genetic testing for XP gene mutations and family counseling could help in early diagnostics and aid in assisting family members. Furthermore, the genotypic variety of XP determines the various clinical manifestations observed in the disease.

There is a complex relationship between the clinical diseases and the molecular defects in NER. Patients with one of several clinical diseases may have inherited a defect in one of several different NER genes. Since the NER pathway functions in sequence, a defect in one part of the pathway impairs the function of the subsequent steps..$^{14}$ Many of the $X P A, X P B, X P D$, and $X P G$ individuals exhibit a severe NER deficiency ${ }^{15}$ whereas individuals with $X P V$ variant show the least aggressive disease, have better prognosis, and enjoy higher life expectancy. ${ }^{1}$ Also, it appears that individuals who only have a partial NER defect, like $X P F$ and $X P C$ patients, tend not to develop neurologic symptoms at all or develop them later in life as compared with patients with more severe NER defects. ${ }^{15}$ Our patient did not develop neurologic symptoms and presented ocular issues later in life. Neurological degeneration is observed in $20 \%-30 \%$ of homozygous patients with mutation in XPA or XPD. ${ }^{16}$ Molecular analyses were not performed in our case, but the diagnosis could be established on a clinical basis.

The public unified health system serves the majority of the Brazilian population. The unified public health system was created by the Brazilian Federal Constitution in 1988, and it is administrated by the Ministry of Health, with subsystems in each Brazilian State and city. However, only in 2014 did the Ministry of Health issue guidelines for complete assistance to be given to individuals with rare disorders. ${ }^{17}$ Hopefully with these national actions, the scenario presented here might improve and molecular analyses could be performed to help diagnose XP as early as possible.

\section{Consent statement}

The authors have tried, unsuccessfully, to obtain written informed consent for publication of this case from the patient's next of kin. The case has been sufficiently anonymized so as not to cause harm to the patient or their family.

\section{Disclosure}

The authors report no conflicts of interest in this work.

\section{References}

1. Chaibub SCW. Alta incidência de xeroderma pigmentosum em comunidade no interior de Goiás. [High incidence of xeroderma pigmentosum in the community of Goias] Surg Cosmet Dermatol. 2011;3: 81-83.

2. Miraglia E, Curatolo P, Rotunno R, et al. Xeroderma pigmentosum: the children of the night. Case report and review of the literature. Prevent Res. 2012:2(4):388-393.

3. Soltys DT. Análise da natureza genotípica de pacientes com Xeroderma Pigmentoso brasileiros [tese]. [Analysis of the genotypic nature of Brazilian Xeroderma Pigmentosus patients [thesis]] São Paulo, Brazil: Instituto de Ciências Biomédicas, Universidade de São Paulo; 2010:155.

4. Cleaver JE. Common pathways for ultraviolet skin carcinogenesis in the repair and replication defective groups of xeroderma pigmentosum. J Dermatol Sci. 2000;23(1):1-11.

5. DiGiovanna JJ, Kraemer KH. Shining a light on xeroderma pigmentosum. J Invest Dermatol. 2012;132(3 Pt 2):785-796.

6. Bradford PT, Goldstein AM, Tamura D, et al. Cancer and neurologic degeneration in xeroderma pigmentosum: long term follow-up characterises the role of DNA repair. J Med Genet. 2011;48(3):168-176.

7. Kraemer KH, Lee MM, Andrews AD, Lambert WC. The role of sunlight and DNA repair in melanoma and nonmelanoma skin cancer. The xeroderma pigmentosum paradigm. Arch Dermatol. 1994;130(8): 1018-1021.

8. Giannelli F, Avery J, Polani PE, Terrell C, Giammusso V. Xeroderma pigmentosum and medulloblastoma: chromosomal damage to lymphocytes during radiotherapy. Radiat Res. 1981;88(1):194-208.

9. DiGiovanna JJ, Patronas N, Katz D, Abangan D, Kraemer KH. Xeroderma pigmentosum: spinal cord astrocytoma with 9-year survival after radiation and isotretinoin therapy. J Cutan Med Surg. 1998;2(3):153-158.

10. Rouillon $\mathrm{C}$, White MF. The evolution and mechanisms of nucleotide excision repair proteins. Res Microbiol. 2011;162(1):19-26.

11. de Boer J, Hoeijmakers JH. Nucleotide excision repair and human syndromes. Carcinogenesis. 2000;21(3):453-460.

12. Neto CF. Melanoma. Boletim informativo do GBM. 2003; ano V(20):1-4.

13. Rubió Casadevall J, Graña-Suárez B, Hernandez-Yagüe X, Vayreda Ribera J, HucGrasa O, Brunet Vidal J. Xeroderma pigmentosum: neck lymph node metastasis of a squamous cell carcinoma of the skin treated with cetuximab. Eur J Dermatol. 2009;19(2):163-165.

14. Kraemer KH, Patronas NJ, Schiffmann R, Brooks BP, Tamuraa D, Digiovannaa JJ. Xeroderma pigmentosum, trichothiodystrophy and cockayne syndrome: a complex genotype-phenotype relationship. Neuroscience. 2007;145(4):1388-1396.

15. Bootsma D, Kraemer KH, Cleaver JE, Hoeijmakers JHJ. Nucleotide excision repair syndromes: xeroderma pigmentosum, cockayne syndrome and trichothiodystrophy. In: Vogelstein B, Kinzler KW, editors. The Genetic Basis of Human Cancer. New York, NY: McGraw-Hill; 2008:245-274. 
16. Menck CF, Munford V. DNA repair diseases: what do they tell us about cancer and aging? Genet Mol Biol. 2014;37(Suppl 1):220-233.

17. Passos-Bueno MR, Bertola D, Horovitz DDG, Ferraz VEF, Brito LA. Genetics and genomics in Brazil: a promising future. Mol Genet Genomic Med. 2014;2(4):280-291.

18. Wikimedia commons. [webpage on the Internet]. Basal Cell Carcinoma. Available from https://commons.wikimedia.org/wiki/File:Basal_cell_ carcinoma.jpg. Accessed May 23, 2018.

19. Alergodermatoligia. [blog on the Internet]. Available from http:// alergodermatologia.blogspot.com.br/2008/06/cncer-da-pele.html. Accessed May 23, 2018.
20. Wikimedia Commons [webpage on the internet]. Basal cell Carcinoma histopathology. Available from: https://commons.wikimedia.org/wiki/ File:Basal_cell_carcinoma_histopathology_\%283\%29.jpg. Accessed May 23, 2018.

21. Faculty of Medical Sciences of the State University of Campinas (UNICAMP). Pathological Anatomy, Neuropathology and Neuroimaging. [webpage on the Internet]. Avaiable from http://anatpat.unicamp.br/. Accessed May 23, 2018.

22. Wikipedia. [website on the Internet]. Available from https://pt.wikipedia. org/wiki/Melanoma\#/media/File:Melanoma.jpg. Accessed May 23, 2018.

\section{Publish your work in this journal}

The Application of Clinical Genetics is an international, peer-reviewed open access journal that welcomes laboratory and clinical findings in the field of human genetics. Specific topics include: Population genetics; Functional genetics; Natural history of genetic disease; Management of genetic disease; Mechanisms of genetic disease; Counselling and ethical issues; Animal models; Pharmacogenetics; Prenatal diagnosis; Dysmorphology. The manuscript management system is completely online and includes a very quick and fair peer-review system, which is all easy to use. Visit http://www.dovepress.com/testimonials.php to read real quotes from published authors. 